\title{
The Concept of Love in Shakespeare's Sonnets
}

\author{
Fenghua Ma \\ School of Foreign Languages, Jiangsu University, 212013 Zhenjiang, China
}

\begin{abstract}
The present paper probes into the concept of love revealed in the Dark Lady group in Shakespeare's Sonnets. In these poems, the poet depicts a kind of obsession, bitter, hopeless and degenerating, which is totally different from that sweet and ennobling love Shakespeare always pursues in his early works. It is argued that the conflict between the ideal of love and the sensual obsession with the Dark Lady may well be a manifestation of the change in the poet's mood, namely, from optimism to pessimism.
\end{abstract}

Index Terms - the concept of love, Dark Lady, Shakespeare's Sonnets

\section{INTRODUCTION}

Since there are more legends than documented facts about Shakespeare's life, his life, in a sense, remains a mystery. Just for this reason, there were plenty of scholars who read Shakespeare's sonnets as his autobiography. In "Scorn Not the Sonnet", for instance, Wordsworth wrote, "with this Key/ Shakespeare unlocked his heart..." (Gill, 2000, p.356). Although this argument is still open to discussion, many scholars seem to believe that sonnets, as lyrical poems, tend to convey more personal implications than other literary forms. Therefore, Shakespeare's Sonnets bears a special meaning to his whole career of literary creation. These 154 sonnets, with their profound thought, luxuriant images, sincere and oceanic emotion, as well as artistic fascination, can by all means draw a parallel to his enduring plays.

In the past four hundred years, considerable research effort has been made to unravel the mystery of this sonnet sequence. Amid the numerous and diverse research concerning the sonnets, there are three major areas of debate: the date of their composition; the possible real-life identities of Mr. W. H. to whom they are dedicated and of the friend, the rival poet, and the dark lady who appear in the poems; and the extent to which the sonnets, either in their traditional sequence or in some rearrangement, tell a unified story that may be rooted in Shakespeare's personal experience (Zesmer, 1976, p.76-77).

Let there be various means to divide Shakespeare's career, it may be safe to proclaim that the great change in Shakespeare's literary creation, namely, the change from comedies to tragedies, in all probability, was brewed in the late sixteenth and early seventeenth centuries. This change may likewise reveal the turn in Shakespeare's world view and his outlook on life. He became less optimistic, if not pessimistic. Despite the fact that the exact date of its composition is still unavailable, it is comparatively easy to prove that Shakespeare's Sonnets was started in the early years of the 1590s, and the bulk of them had been completed by the end of the sixteenth century. Since the years spent on the composition of the sonnets, coincide with the several years that witnessed Shakespeare's great change in literary creation, is it likely that the poet's attitude in the sonnets, for example, his attitude to love, undergoes a similar change?

No matter how dense the debate on identity, date, and order may be, critics who differ on various interpretive problems are likely to agree that the direction of address of these poems can be established with certainty: the first 126 sonnets refer to and are generally addressed to the Fair Friend, while the succeeding ones concern the Dark Lady (Dubrow, 1998, p.238). The Dark Lady group will be the focus of the present paper. By comparing the "love" described in this group of poems with the concept of love reflected in Shakespeare's early works and that prevailed in the Renaissance, this paper endeavors to investigate into the change in the poet's attitude to love.

\section{The RenAissance CONCEPT OF LOVE}

The concept of love that prevailed over the Renaissance period was the so-called Courtly Love. Courtly Love (known in medieval France as "fine love" or fin amour) is "an example of an idea about heterosexual relationships" (Cuddon, 1977, p.165). Though it is susceptible to interpretations or expressions of various kinds, "there appear to be some fundamental elements which are fairly universal: (a) the four marks of courtly love are humility, courtesy, adultery and the religion of love; (b) the love is desire; (c) it is an ennobling and dynamic force; (d) it generates a cult of the beloved" (Cuddon, 1977, p.165). In the brilliant sonnet sequences of Philip Sidney and Edmund Spenser in the sixteenth century, this tradition finds its full expression in England. Most of these sequences follow the ancient tradition: women are idealized; the lover, stricken by both spiritual and personal beauty of his lady, owes her obedience and submission; the love the lover pursues has the power to purify his souls and ennobles him; and the lover longs for union with his lady in order to attain moral excellence.

Nevertheless, the courtly love in England has features of its own. In the time of Renaissance, most of the English poets tended to believe that the sensual love was a kind of desire; however, not every desire could be regarded as love (Hu, 2001, p.135). Accordingly, they neither idealized love to a purely spiritual being, nor rendered a total repudiation 
to the sensual love. Generally speaking, what characterized the English courtly love were its concerns, which attached importance both to the earthly (sensual) and to the heavenly (spiritual) aspects of love, with an obvious preference for the spiritual. In their opinion, the spiritual love which was lofty and sacred was naturally superior to the sensual one. John Donne, one of the greatest metaphysical poets, in his renowned "A Valediction: Forbidding Mourning”, says,

Dull sublunary lovers' love

(Whose soul is sense) cannot admit

Absence, because it doth remove

Those things which elemented it.

But we, by a love so much refined

That our selves know not what it is

Inter-assured of the mind,

Care less, eyes, lips, and hands to miss. (Abrams, 1988, p.1070)

Here the poet tolerates the sensual or earthly love, but a favor and cult towards the spiritual one is easy to discern. However, sensual love does not equal lust. The poets of the present age made an extremely clear distinction between lust and true love. To them, lust results in sensual sloth while love leads to heroic action. Spenser, for example, in his Amoretti, a sonnet sequence concerns the relationship between the spiritual love and the sensual one, expresses his attitude towards lust and true love in plain words:

Such loue not lyke to lusts of baser kynd,

The harder wonne, the firmer will abide.

The durefull Oake, whose sap is not yet dride,

Is long ere it conceiue the kindling fyre:

But when it once doth burne, it doth diuide

Great heat, and makes his flames to heauen aspire.

(Sonnet 6) (Spenser \& Larsen, 1997, p.71)

He thinks that lust is base, while true love is faithful and persistent, and bears something divine that is connected with the kingdom of heaven. His point of view represents the prevailing attitudes to love of the time.

\section{ThE CONCEPT OF LOVE IN SHAKESPEARE’s EARLY WORKS}

Love is, more often than not, a major theme of Shakespeare's early works, for example, The Two Gentlemen of Verona (1594), Love's Labor's Lost (1594), Romeo and Juliet (1595), A Midsummer Night's Dream (1596), The Merry Wives of Windsor (1598) and Twelfth Night, or What You Will (1600). Despite the fact that he expresses deep concern about the theme of love in every single play, Shakespeare never tries to make a tidy definition of it. However, from these plays, it is comparatively easy to detect what on earth love means in the mind of Shakespeare.

To begin with, in Love's Labor's Lost (1594), King Ferdinand of Navarre and his friends Longaville, Dumain, and Berowne take an oath to overcome the frailties of the flesh and spend three years in scholarly seclusion. Almost immediately their absurd vows are assaulted by the diplomatic visit of the Princess of France and her three beautiful attendants. The four would-be scholars in quick turn fall in love, forswear their vows, and are conquered by the overwhelming power of love. Through Berowne,

As true we are as flesh and blood can be:

The sea will ebb and flow, heaven show his face;

Young blood doth not obey an old decree:

We cannot cross the cause why we were born;

Therefore of all hands must we be forsworn.

(Act 4, Scene 3) (Wilson, 1962, p.53)

Shakespeare argues that love is, in words of the Countess in All's Well that Ends Well (1602), "the show and seal of nature's truth" (Act 1, Scene 3) (Wilson, 1968, p.17). To love is but human nature. And the power of love is encompassing and invincible.

Furthermore, in The Two Gentlemen of Verona (1594), Romeo and Juliet (1595), A Midsummer Night's Dream (1596), and The Merry Wives of Windsor (1598), love manifests itself in a loftier way. In The Two Gentlemen of Verona (1594), probably Shakespeare's earliest romantic comedy, when Silvia, the female protagonist, is in the apparently hopeless plight of the Proteus' violent court, she still turns him down without any hesitation and professes bravely,

Had I been seized by a hungry lion,

I would have been a breakfast to the beast,

Rather than have false Proteus rescue me.

$\mathrm{O}$, Heaven be judge how I love Valentine,

Whose life's as tender to me as my soul!

(Act 5, Scene 4) (Wilson, 1955a, p. 71)

The single word "soul" indicates the pureness and sacredness of true love, and sublimates love to the spiritual highness. Then in A Midsummer Night's Dream (1596), once again, Shakespeare reveals his understanding of love in Helena's bitter monologue: 
And as he errs, doting on Hermia's eyes,

So I, admiring of his qualities:

Things base and vile, folding no quantity,

Love can transpose to form and dignity:

Love looks not with the eyes, but with the mind;

And therefore is wing'd Cupid painted blind:

(Act 1, Scene 1) (Wilson, 1969, p.10)

Love is blind. It does not care appearances, social status, financial conditions, and things like this. It seems to be quite irrational, but from another perspective, this kind of love reflects that Shakespeare, as a humanist, gives higher regard to the communication of minds or spirits between lovers. Another instance may be The Merry Wives of Windsor (1598). Although Falstaff is the leading figure, one cannot help being fascinated by the secondary plot: the elaborate deception whereby Anne Page marries her truelove Fenton, while her father has promised her to the well-off Slender and her mother prefers Dr. Caius, a French physician, who not only is well-moneyed but also has a friend at court. At the very beginning, Fenton proposes to Anne Page with the purpose of obtaining her father's considerable wealth, but when he really falls in love with her, he confesses:

No, heaven so speed me in my time to come!

Albeit I will confess thy father's wealth

Was the first motive that I woo'd thee, Anne:

Yet, wooing thee, I found thee of more value

Than stamps in gold or sums in sealed bags;

And 'tis the very riches of thyself

That now I aim at.

(Act 3, Scene 4) (Wilson, 1954, p.55)

Here Fenton beholds the look of true love. He comes to realize that Anne is what he desires, and she, herself, is the very thing that he wants to cherish for his life time. His soul is purified by the power of love.

In addition, love, in Romeo and Juliet (1595), becomes a strong might that encourages the lovers to thread their way through obstacles set up by middle aged vanity and impercipience, and even to sacrifice their precious lives without wavering. From these examples, it may be safe to believe that though he is not against the sensual love, Shakespeare pays much more attention to the spiritual power of true love, in other words, in his opinion, compared with the sensual love, the spiritual one is of greater worth. Like his contemporaries, Shakespeare also feels contempt for lust, Adonis' comparison of love and lust may be a fine instance:

"Love comforteth like sunshine after rain,

But Lust's effect is tempest after sun;

Love's gentle spring doth always fresh remain,

Lust's winter comes ere summer half be done;

Love surfeits not, Lust like a glutton dies;

Love is all truth, Lust full of forged lies.'

("Venus and Adonis", Lines 799-804) (Wilson, 1966a, p.31)

To sum up, in these early works, Shakespeare's concept of love enjoys great similarities with those of his contemporaries' - a preference for the spiritual love and scorn for lust. The love appears in Shakespeare's early works takes on a bright and optimistic look. It acts as a positive power that contains inexhaustible potentials.

\section{THE TRAGIC LOVE WITH THE DARK LADY}

It is a common belief that Sonnets 127-54 shift the poetic focus away from the Fair Friend to the notorious Dark Lady. It is a tradition for the Renaissance poets to experience and incarnate the sum of life's power and perfections in the beauty of their chaste and elegant ladies, such as Sidney's Stella, Daniel's Delia and Constable's Diana. Unlike his contemporaries, Shakespeare's sonnets to the Dark Lady dwell on her imperfections and falsehoods. Seldom does the enthusiastic praise of the beloved one, which frequents most the Shakespeare's early works, appear in this group of poems dedicated to his mistress. Furthermore nearly every sonnet of this group involves some accusation against her. In Sonnet 131 the Dark Lady is condemned as "tyrannous" (Wilson, 1966b, p.68), in Sonnet 133, as faithless, in Sonnet 134 as "covetous" (Wilson, 1966b, p.69); in Sonnet 137 she is "the bay where all men ride...the wide world's common place" (Wilson, 1966b, p.71); in Sonnet 138 she is described as "false" (Wilson, 1966b, p.71), in Sonnet 139 as "unkind" (Wilson, 1966b, p.72), in Sonnet 140 as "proud" (Wilson, 1966b, p.73), in Sonnet 142 as "false to the bonds of love" (Wilson, 1966b, p.73); in Sonnet 147, she is "black as hell, dark as night" both in appearance and in character (Wilson, 1966b, p.76); in Sonnet 148 she is considered to be full of "foul faults" (Wilson, 1966b, p.76); in Sonnet 149, she is "cruel" (Wilson, 1966b, p.77); in Sonnet 150, she is described as "unworthy" but of "a powerful" might to seduce the poet (Wilson, 1966b, p.77); and then in Sonnet 152, she is inconsistent as well as unfaithful. The poet knows only too well his mistress' defects,

In nothing art thou black save in thy deeds,

And thence this slander, as I think, proceeds. 
(Sonnet 131) (Wilson, 1966b, p.68)

Here black has not remained a color; it has "become synonymous with evil, moral corruption, perhaps unbridled sexuality" (Smith, 1981, p.50). However he cannot do anything but devote himself to the obsession with her. And thus infatuation for an unworthy woman becomes the main theme of the Dark Lady poems.

As far as the poet is concerned, the power of the Dark Lady is mesmerizing, enslaving as well as corrupting. She "appears to be the archetypal 'belle dame sans merci', the literary precursor of Keat's 'Belle Dame' and Coleridge's Geraldine, with power to captivate and to corrupt" (Sarkar, 2000, p.348). The poet's relationship with the Dark Lady is a relationship of enchantment and enchainment of a soul-destroying intensity. The poet expresses his chaotic emotion through the conflict between eye and heart, which is the theme of many sonnets:

In faith, I do not love thee with mine eyes,

For they in thee a thousand errors note;

But 'tis my heart that loves what they despise,

Who in despite of view is pleased to dote.

Nor are mine ears with thy tongue's tune delighted,

Nor tender feeling, to base touches prone,

Nor taste, nor smell, desire to be invited

To any sensual feast with thee alone.

But my five wits nor my five senses can

Dissuade one foolish heart from serving thee,

Who leaves unswayed the likeness of a man,

Thy proud heart's slave and vassal wretch to be:

(Sonnet 141) (Wilson, 1966b, p.73)

As a matter of fact, both the five wits (intellectual faculties) and the five senses combat the poet's enthrallment to the mistress; it comes entirely from the foolish heart. Sonnet 137 and Sonnet 152 deal with the similar theme of the corruption of the eye. Eyes are supposed to collect all kinds of images and transmit them to the brain. They should do their utmost to see the truth, the fact, and then report it, but in the situation of Sonnet 137,

Thou blind fool, Love, what dost thou to mine eyes

That they behold and see not what they see?

They know what beauty is, see where it lies,

Yet what the best is take the worst to be.

If eyes corrupt by over-partial looks

Be anchored in the bay where all men ride,

Why of eyes' falsehood hast thou forged hooks,

Whereto the judgment of my heart is tied?

Why should my heart think that a several plot

Which my heart knows the wide world's common place?

Or mine eyes seeing this, say this is not,

To put fair truth upon so foul a face?

In things right true my heart and eyes have erred,

And to this false plague are they now transferred. (Wilson, 1966b, p.71)

The very perjury of the eye forces the poet into a pathetic corner. And the vehement clash between the sense and sensibility gives rise to the poet's pessimistic moods which permeate the Dark Lady series.

The poet's sense of despair and bondage in the relationship with the Dark Lady is acknowledged in sonnet after sonnet. Some time ago, in Shakespeare's early works, love is bright and, to some extent, an ennobling force; the beloved are lovely and fair, pure and true. They are compared to "bright angel" (Romeo and Juliet) (Wilson, 1955b, p.32), "the sun that maketh all things shine" (Love's Labor's Lost) (Wilson, 1962, p.54) and things alike, which obviously shed some light on the optimistic attitudes of the writer. Nevertheless, in these sonnets devoted to his mistress, the poet draws the comparisons of his infatuation or love to something unpleasant, which conveys anything but optimistic implications. For instance,

My love is as a fever, longing still

For that which longer nurseth the disease,

Feeding on that which doth preserve the ill,

Th'uncertain sickly appetite to please.

(Sonnet 147) (Wilson, 1966b, p.76)

Here love is a fever. Then in Sonnet 137 and Sonnet 141, it is a "plague" (Wilson, 1966b, p.71, p.73). It is also "madness" in Sonnet 140 (Wilson, 1966b, p.72). But what pushes the poet into a more despairing situation is that sometimes he finds that his relationship with the Dark Lady turns out to be mere lust, for which he always feels contempt. As some critics argues, the sonnets to or about the Dark Lady are sometimes adulatory, sometimes analytical, sometimes frivolous; they reflect submission, evasion, and sometimes disgust; they are "poems of lust" (Smith, 1981, p.60). The sexual implications of "will" (Sonnets 135-36) and the pun of "lie" (Sonnet 138) have often been pointed out 
and are undeniably there. Take the famous Sonnet 129 as an example, which is probably one of the most violent sonnets of the entire sonnet sequence. It is in some sense a kind of definition or analysis of Lust.

Th'expense of spirit in a waste of shame

Is lust in action; and till action, lust

Is perjured, murd'rous, bloody, full of blame,

Savage, extreme, rude, cruel, not to trust,

Enjoy'd no sooner but despised straight,

Past reason hunted and no sooner had,

Past reason hated as a swallowed bait

On purpose laid to make the taker mad;

Mad in pursuit, and in possession so,

Had, having, and in quest to have, extreme,

A bliss in proof, and proved, a very woe,

Before, a joy proposed, behind, a dream.

All this the world well knows, yet none knows well

To shun the heaven that leads men to this hell. (Wilson, 1966b, p.67)

The poet attacks strongly upon lust in this poem. He elaborates on it through the images of war, murder, savagery, cruelty, hunting, and baiting. However, all these severe criticisms end with a hopeless couplet-everybody knows this perfectly well, but nobody is wise enough to escape from it, with the poet himself included. Despite the very fact that the poet despises erotic love, he cannot resist the temptation from his mistress. Sonnet 151 is a clear example:

For, thou betraying me, I do betray

My nobler part to my gross body's treason:

My soul doth tell my body that he may

Triumph in love; flesh stays no farther reason... (Wilson, 1966b, p.78)

In short, the poet's situation is tragic, in which he suffers, struggles, and despairs. He loves a woman he really has every reason to despise. He knows that the Dark Lady is only a "bad angel", "the worser spirit" (Sonnet 144) (Wilson, 1966b, p.74), and repeatedly he indicates that his love towards the woman is sinful, disfiguring as well as defiling, but he just has no way out. Hence, from all perspectives, this kind of love is hopeless, and may well turn out to be a failure or tragedy. As a matter of fact, through some hints revealed in the sonnet sequence, for example,

So, now I have confessed that he is thine,

And I myself am mortgaged to thy will,

Myself I'll forfeit, so that other mine

Thou wilt restore to be my comfort still.

But thou wilt not, nor he will not be free,

For thou art covetous and he is kind;

(Sonnet 134) (Wilson, 1966b, p.69)

it is a tradition to believe that the Dark Lady really betrays the poet by seducing the Fair Friend. The betrayals of both his Fair Youth and his beloved mistress throw the poet into an agony of pain.

\section{CONCLUSION}

It was the courtly love that enjoyed great popularity in the Renaissance. It advocated the spiritual love which was sacred and ennobling. Although the English poets did not repudiate to the sensual love totally, they took a disgust at lust. In his early works, like his contemporaries, Shakespeare expressed a similar insight of love. He also spared no pains to pursue a love with a lofty and pure nature. But in the Dark Lady poems a love for an unworthy object becomes a dominant theme. The poet's so-called love or uncontrollable passion for a woman he really despises pushes him into an extremely desperate situation. He knows each and every defect of the Dark Lady; he knows this kind of blind and foolish love for her is, to a great extent, similar to lust in nature; he knows he should in all senses disdain this wanton mistress; however, he just can find no way to get rid of this stupid and desperate obsession for her. Hence the tragic vision reveals itself. The conflict between the ideal of love and the sensual obsession with the contemptible Dark Lady may well offer testimony to the poet's change from optimism to melancholy.

\section{REFERENCES}

[1] Abrams, M. H. (ed.) (1988). The Norton anthology of English literature: Vol. 1 (4th ed). New York: W. W. Norton \& Company, Inc.

[2] Cuddon, J. A. (1977). A Dictionary of Literary Terms. Revised edition. Harmondsworth: Penguin Books Ltd.

[3] Dubrow, H. (1998). Incertainties now crown themselves assur'd: The Politics of Plotting Shakespeare's Sonnet. Shakespearean Criticism 40, 238-247.

[4] Gill, S. (ed.) (2000). William Wordsworth: The Major Works. Oxford: Oxford UP.

[5] Hu J. L. (2001). The Starry Heavens: English Renaissance Poetry and Traditional Cosmology. Beijing: Peking UP.

[6] Sarkar, M. (2000). The Magic of Shakespeare's Sonnets. Shakespearean Criticism 48, 346-351. 
[7] Smith, H. D. (1981). Tension of the Lyre: Poetry in Shakespeare's Sonnets. San Marino: The Huntington Library.

[8] Spenser, E., \& Larsen, K. J. (eds.). (1997). Edmund Spenser's Amoretti and Epithalamion: A critical edition. Tempe, AZ: Medieval \& Renaissance Texts \& Studies.

[9] Wilson, J. D. (ed.) (1954). The Merry Wives of Windsor. New York: Cambridge University Press.

[10] Wilson, J. D. (ed.) (1955a). The Two Gentlemen of Verona. New York: Cambridge University Press.

[11] Wilson, J. D. (ed.) (1955b). Romeo and Juliet. New York: Cambridge University Press.

[12] Wilson, J. D. (ed.) (1962). Love's Labour's Lost. New York: Cambridge University Press.

[13] Wilson, J. D. (ed.) (1966a). The Poems. New York: Cambridge University Press.

[14] Wilson, J. D. (ed.) (1966b). The Sonnets. New York: Cambridge University Press.

[15] Wilson, J. D. (ed.) (1968). All's Well that Ends Well. New York: Cambridge University Press.

[16] Wilson, J. D. (ed.) (1969). A Midsummer Night's Dream. New York: Cambridge University Press.

[17] Zesmer, D. M. (1976). Guide to Shakespeare. New York: Barnes \& Noble Books.

Fenghua Ma is a lecturer in the English Department, School of Foreign Languages at Jiangsu University. Her research interests include English literature and American literature. 